\title{
Perceptions of Marriage and Human Relationships in Jane Austen's Novel Emma
}

\author{
Eljvira Kica \\ South East European University, Tetovo, R. Macedonia
}

Doi: 10.19044/esj.2017.v13n32p65 URL:http://dx.doi.org/10.19044/esj.2017.v13n32p65

\begin{abstract}
Emma is a novel written by Jane Austen, which is based on real- life situations of the eighteenth century England. Austen depicts her novels to show clearly the customs and traditions that people had to use in order to get married; her dissatisfaction towards all these conditions; male dominance and also the consideration of women as weak human beings with limited rights. Based on all these issues, Austen chooses different kinds of marriages, mainly based on economical interest. Most of the people in her novels see the marriage as an obligation which had to be fulfilled; most of the girls got involved into a marriage market where parents decided what was good or bad for them. This paper describes the conditions of unmarried and married women Emma; the ways how the unmarried women chose the partners; the ways how Austen compared the conditions of women with the real life situations of the eighteenth century Britain; how she used irony to show her dissatisfaction towards the traditions of that time, and also the real message she conveys to the world.
\end{abstract}

Keywords: Unmarried, married, women, couples, interest, money, love, feelings

\section{Introduction}

Emma is a novel which tells the story of Emma, a "handsome, clever, and rich, with a comfortable home" (Austen, 2014). Being a child of a family with good economical conditions, Emma was not a girl who had to find a husband as the only escape from poverty. As most of other novels, in Emma Austen focuses and explores the lives of women during the period of the eighteenth century especially marriage, which was the main issue of women during that period. In the novel, Austen involves different characters, including characters that belonged to upper classes and lower classes and their struggle to achieve where they wanted. The story flowed in a way that Emma understood her mistakes and changed her opinion about marriage by marrying 
Mr. Knightley. On the other hand, other couples were involved in difficult situations, struggled to find the appropriate partner and achieve to marry either for love, affection or money. Since the main aim of this paper was to analyze the situations and the relationships of the unmarried characters who ended up married by the end of the novel and also the relationships of the already married couples of the novel, the main analysis was based on Emma Woodhouse and her relationship with Mr. George Knightley, Jane Fairfax and her relationship with Frank Churchill, Harriet Smith and her relationship with Robert Martin, Augusta Hawkins and her relationship with Philip Elton, and also the relationships of the already married couples, Anne Taylor Weston and Mr. Weston, and the relationship of Isabella Woodhouse and John Knightley.

\section{Unmarried in Emma}

\section{Jane Fairfax and Frank Churchill}

In the novel Austen presents Jane Fairfax as a young, twenty- one year old girl, very intelligent, whose parents died when she was just a small child. The fact that Jane had no siblings made her tie her relationships with the Campbells, relatives of her family. Jane "had fallen into good hands, known nothing but kindness from the Campbells, and been given an excellent education. Living constantly with right- minded and well- informed people, her heart and understanding had received every advantage of discipline and culture" (Austen, 2014). Based on the fact that Jane was an orphan, her only hope was either to find a job as a governess or to get married in order to survive. The fact that during the period of the eighteenth century the only job that an educated woman could have was that of a governess did not leave many options to Jane. Even though, Jane knew that being a governess was not an ideal job, again she had to accept it since she did not have other alternative. As Dobosiova states: “....as good as she is clever and as clever as she is beautiful. But it is also true that Jane Fairfax is an unprovided woman with no prospects in life beyond those of earning her living as governess at Mrs. Smallridge's and passing her hardened holidays with Miss. Bates" (Dobosiova, 2006). The time when Jane had given up the idea of finding a husband due to her economical conditions and accepting the fact that she had to work as a governess was the time when in town appeared Frank Churchill, with whom Jane got engaged secretly. Kaye- Smith describes Frank to be "a sympathetic study of a charming playboy, spoilt, as much by the repressions of his upbringing as dy its indulgences" (Kaye- Smith; Stern, 1943). Frank inherited a great fortune from his aunt, which fortune gave to Frank a pride; meantime, a great limitation to his own wishes and feelings. Austen describes the relationship of Jane and Frank as a very complex relationship. In fact, their relationship began from the very first beginning of the novel, but it was revealed only by the end of the novel. The fact that Frank's aunt would not 
accept Frank to marry a penniless orphan did not allow Frank to reveal his engagement to Jane. Moreover, Frank's interests to inherit the Churchill's property, to maintain harmony in his Escombe world and to secure his fortune, stopped him from revealing his secret engagement. To avoid the situation of revealing the engagement, Frank behaved irresponsibly in his attentions to Jane by flirting with Emma. Gilbert and Gubar define Jane's story as the story of a "passive and quiet girl, humiliated by her lover" (Gilbert; Gubar, 2000). All these situations brought a lot of disappointment to Jane, and she decided to break her engagement. Only after his aunt's death, Frank returns to Jane and understands that he loves her. He proposes her for the second time, and she accepts his proposal. Hall states about the marriage of Frank and Jane that "marriage to Frank Churchill is only a good because it is better than the alternative-paid servitude as a governess" (Hall, 2017). In her book, Reader, I Married Him, Beer expresses her anger towards Frank by saying:

Throughout the book he seems to be punishing Jane Fairfax for having stopped to a secret engagement with him though he coerced her into it with treats of going mad. His account of their final quarrel acknowledges with amost indecent honesty his wish to hurt her (Beer, 1974).

During the period of the eighteenth century marriages between upper and lower classes happened only when "the floundering aristocracy was enriched through their union with a wealthy merchant- class family, thereby making it incredibly difficult for a member of the lower or middle class without wealth or social standing to marry into a family with both" (Campbell, 2012). Regarding this fact, the marriage of Jane and Frank represents a marriage which is not very realistic for that period. Austen tries to show that these kinds of marriages should exist for the fact that money should not be considered as the only means for marriage. As long as there is love, everything is possible. Even though, the relationship of Jane and Frank knocks the bounders of matching two people of different social and economical classes, again this relationship goes through many obstacles. The marriage of Frank and Jane is a clear reflection of the women's position during the eighteenth century. This relationship shows clearly that educated, clever girls were not valued and respected in a level they deserved. Austen gives the message that people should marry for love and exchange mutual respect regardless the economical position. Money should not be considered as the main source for making someone clever, respectful, and desirable person. Money cannot buy people's way of thinking. Education and intelligence make a person clever enough to live life by striving to earn money and value that money as a part of your hardwork and successful result. 


\section{Emma Woodhouse and George Knightley}

Emma is the main character of the novel. She was a girl whose mother had died and lived with her father, Mr. Woodhouse. Austen describes Emma to be "handsome, clever, and rich, with a comfortable home and happy disposition, seemed to unite some of the best blessings of existence..."(Austen, 2014). Even though, it was not very common for women of the eighteenth century to stay single, without taking into account the wealth that these women possessed, again Emma showed no interest to marry. Regarding the high economical position that Emma belonged to, Butler states that "Austen situates Emma in a superior social position in order to allow her the freedom to 'act out willful errors for which she must take entire moral responsibility" (Butler, 1986). Being aware of the fact that Emma did not want to marry, she got herself involved in matchmaking. Matchmaking became a part of Emma's life, which afterwards proved that it lead Emma to many mistakes. Lambdin and Lambdin consider Emma to be a naïve person based on the fact that she gets involved in matchmaking, by saying: "Emma is a naïve about both herself and the outside world; she must learn her own limitations and resist the temptation to remake her world within her imagination" (Lambdin; Lambdin, 2000). The only person who opposed to Emma's actions was George Knightley. Mr. Knightley was an old friend of Emma's family and the brother-in-law of Isabella, Emma's sister. As George was much older than Emma, he knew Emma's character and personality, and he did not like the fact that Emma took some actions which he supposed were wrong. George always had the tendency to criticize Emma for her matchmaking actions: "You are more likely to have done harm to yourself, than good to them, by interference" (Austen, 2014). Emma's matchmaking mistakes lead to the understanding about the naivety of women in general and their incapable role to manage things that they believed were in their hands. Since men were educated and could manage different businesses, inheritances or other investments, women of the eighteenth century were supposed to manage their families, their housework and also their everyday task, matchmaking. Her failure to match other people represents a gender failure as well. This means that women of the eighteenth century were not capable to accomplish their duties of that time, failing in their tasks and creating a mass in society by harming other people. Even though Emma was seen as a rich, independent person, again her mistakes and failures make us understand Austen's revolt towards women themselves. George Knightey changed Emma's way of perceiving things. Emma began to be more careful and to show more respect towards other people. Emma began to understand that George Knightley was a very nice person, and his advices changed her for good. Emma understood that she had true feelings for George Knightley; she understood that the only woman who should marry George is no one but herself. "This (was) the 
moment of anagnorisis: the arrow is an arrow of enlightenment as well as of love; what is intended for her as her real fate, however long suspected by the reader, and (was) revealed to the heroine herself in a flash of insight. Although the word 'fate' itself is not used, for Emma to recognize 'that Mr. Knightley must marry no one but herself' is indeed to stare destiny in the face. However, both words, 'fate' and 'destiny' (were) reserved for the climax of Emma's thinking that follows this revelation" (Barfoot, 1982). The marriage of Emma and George is a marriage based on feelings from the very beginning of the novel. George had loved Emma from when she was a young girl. Since Austen describes Emma as being an independent woman, possessing all the wealth and respect in Highbury, Lambdin and Lambdin express their opinion about Emma's character and her marriage with George by saying:

"Emma is Jane Austen's exploration of what a eighteenth-century woman's life would be like if she had the powers and privileges of a man. But independence is a difficult thing for a young person, and although Emma exhibits the 'confidence and presumption usually reserved for Austen's male characters', her inexperience causes her to make 'the serious business of marriage too lightly'. There is significant turmoil within each of the courtships that makes possible the novel's concluding marriages (Harriet's, Jane's and Emma's), but eventually we come to see that each of the marriages is an appropriate union of personalities. Emma's union is the most satisfying because it links two ultimately good characters whose personality traits lend support to each other: Emma brings out Mr. Knightley's subdued passion, and he helps her refine her good sense. Their union is all the more appealing because, unlike some of the marriages that were necessitated by economic demands, Emma's fate was not inevitable" (Lambdin; Lambdin, 2000).

\section{Harriet Smith and Robert Martin}

Austen describes Harriet by saying that she "was not clever, but she had a sweet, docile, grateful disposition, was totally free from conceit, and only desiring to be guided by any one she looked up to. Her early attachment to herself was very amiable; and her inclination for good company, and power of appreciating what was elegant and clever, shewed that there was no want of taste, though strength of understanding must not be expected" (Austen, 2014).

Being simple and naïve, Harriet fell into Emma's judgments, whose main point was to control Harriet's life, change her lifestyle, involve her into a higher social rank and a more luxurious situation, without taking into account Harriet's feelings and her spiritual conditions. Emma's words made Harriet change her opinion towards Robert Martin, a farmer, who loved and cared about Harriet. Being aware of the fact that Harriet loved Martin, Emma used every resource and persuasive words to convince Harriet not to marry Robert 
Martin. Believing that her ideas where right, Emma began her actions to organize the match of Harriet with Elton without even trying to discuss this issue with Harriet. The situation got out of control when Elton proposed Emma, not Harriet. All this situation changed Emma's opinion for herself and repent for her actions. Being aware of the entire situation, accepting her mistakes and feeling guilty for what she had done, Emma advised Harriet to follow her own feelings and follow her heart by making her own decisions. Harriet's and Martin's relationship ended up in a wedding after a very complicated situation they went through. Based on the ways how marriages of the eighteenth century functioned, Austen used Martin's and Harriet's marriage to show the most realistic type or marriage, where Harriet got married within the same social and economical rank, and she did not gain or lose any power. "Harriet's marriage embodies...the theory of cruel optimism because she becomes attached to the idea that she can marry someone like Elton..., while the reality of her situation dictates that Mr. Martin, a farmer, is her only prospect. Moreover, as long as she believes in the ideology of upward mobility through marriage, Harriet eliminates her realistic marriage opportunities, thereby making it more likely that she will end up an old maid, dependent upon her anonymous, absent father until his death, at which point she would be financially orphaned. Her attachment, therefore, can only be described as cruel in its unattainability and harmfulness" (Campbell, 2012).

The marriage of Harriet and Martin represents a marriage based on the social reality. Austen puts her characters in different situations and confronts them with many obstacles in order to match them with different social rank, but again most of the relationships ended up within the same social class. Austen emphasizes the importance of being equal, where she gives priority to happiness. Harriet went through many situations wishing to marry with someone not based on love.

\section{Philip Elton and Augusta Hawkins}

From the very first time that we encounter Philip Elton, we find him to be "very pretty young man, to be sure, and a very good young man..." (Austen, 2014). Mr. Elton was a clergyman, and even though he was not very rich, again he was a very respected for the fact that he had a high position in the country. Elton's intentions to marry someone rich were fulfilled, and he was proud to show this in every aspect. "He had caught both substance and shadow- both fortune and affection, and was just the happy man he ought to be; talking only of himself and his own concerns- expecting to be congratulated- ready to be laughed at- and, with cordial, fearless smiles, now addressing all the young ladies of the place, to whom, a few weeks ago, he would have been more cautiously gallant...The charming Augusta Hawkins, in addition to all the usual advantages of perfect beauty and merit, was in possession of an 
independent fortune, of so many thousand as would always be called ten; a point of some dignity, as well as some convenience..." (Austen, 2014).

Based on all the facts and the relationship of Augusta and Elton, we realize that Augusta's and Elton's marriage is mainly based on money and reputation. The fact that Augusta possessed a high fortune inherited by her father, Mr. Elton married her without having any special feeling for her and without knowing her enough to consider her a lifetime partner. On the other hand, Augusta married Elton only because he was the vicar of Highbury. This was a great chance for her to show what she possessed and believed that money and her marriage with Elton would adjust her in a high social rank. This marriage was considered to be typical for the period of the eighteenth century, where feelings were not the primary issue.

The marriage of Elton and Augusta seems to be very formal, and their relationship does not show any sign for being happily ever after. Austen shows that this marriage is based on money, and marriages based on different social ranks will never make a couple come to an equal understanding because the ideas of these two people are completely different and would never come to an equal agreement.

\section{Married Couples in Emma}

Even though, Emma was mainly based on the complex relationships of unmarried couples that ended up in marriages, there were two couples involved in the novel that were already married from the beginning of the novel or married in the very first beginning of the novel. These two couples were Mr. Weston and Mrs. Weston and Isabella and John Knightley.

\section{Mr. Weston and Mrs. Weston}

We encounter Miss Taylor from the beginning of the novel as the governess of Emma Woodhouse. After the death of Emma's mother, Miss Taylor was the one who looked after Emma and her sister, Isabella. The very close relationship that Emma had with Miss Taylor made Emma wish nothing but see Miss Taylor happy. Since Emma was grown enough to take care of herself, she wanted to see Miss Taylor happily arranged with someone of a great character. Knowing the people of Highbury, she thought of Mr. Weston as the perfect match for Miss Taylor. " Mr. Weston was a man of unexceptionable character, easy fortune, suitable age, and pleasant manners; and there was some satisfaction in considering with what self- denying, generous friendship she had always wished and promoted the match" (Austen, 2014).

In the novel Austen describes Mr. and Mrs. Weston as being happily married and having a great respect towards each other. Austen describes the Weston's marriage as a marriage where the partners are equal in their 
relationship, and they adjust very well with one another. They show a great respect towards each other, discuss about different things and openly support each other's opinions. "They love each other affectionately; Mrs. Weston feels the pain of her husband even more than he does when Frank cannot arrive to see them. Emma often speaks about domestic happiness at Randalls where the Westons live together" (Austen, 2014). Mrs. Weston had a great appearance and she was a very loving, "kind- hearted and musical" (Austen, 2014) person for everyone. "Frank liked her from the very first time he saw her: "Elegant, agreeable manners...tolerably well- looking woman of acertain age; I did not know that I was to find a pretty young woman in Mrs. Weston" (Austen, 2014).The way how Mrs. Weston behaved towards Frank, Mr. Weston's son from his previous marriage, described her as being really a careful person, kind - hearted and generous. She saw in Frank her child that she did not have. When Frank came one night, and he was wet from the rain, Mrs. Weston immediately ran after him and tried to take care of him by saying: "You are not quite so miserable, though, as when you first came. Go and eat and drink a little more, and you will do very well. Another slice of cold meat, another draught of Madeira and water, will make you nearly on a par with the rest of us" (Austen, 2014). In the novel, Mrs. Weston "acts as a surrogate mother to her former charge and, occasionally, as a voice of moderation and reason, although she is the one to yield in arguments more often than not" (Austen, 2013).

Austen's description of the relationship of Mr. and Mrs. Weston shows clearly that the marriage of Mr. and Mrs. Weston is a marriage based on respect, appreciation and tolerance. Austen describes them to be happy with their marriage, regardless their economical position. Compared to the first marriage of Mr. Weston, the second marriage seems to be more comfortable, understandable and happier. Austen shows that money does not make one's life beautiful, as it did not make Mr. Weston's life in his first marriage. As long as there exists respect and love, things can be arranged perfectly without thinking about who should be more superior in a marriage. Equality makes things easier to be achieved and ideas to be combined. The Westons' marriage represents the harmony that couples can achieve through their respect and tolerance. It is a great example for younger generations and conveys the message that money cannot bring happiness as long as there does not exist respect, love and tolerance. In the novel, Mrs. Weston is a great example of a tolerant person who knows how to keep a great relationship by balancing things. She has given an obligation to herself to keep her marriage strong and healthy, by acting in a way which makes them both happy. She portraits a great example of how relationships have to function, and how people have to act in order to make their marriage happier and their life more beautiful. 


\section{John Knightley and Isabella Knightley}

The marriage of John and Isabella represents a typical marriage of the eighteenth century. Austen describes this marriage as a male- dominated marriage, very common for that period. Austen describes this marriage by stating:

Mrs. John Knightley was pretty, elegant little woman, of gentle, quiet manners, and a disposition remarkably amiable and affectionate; wrapt up in her family; a devoted wife, a doating mother, and so tenderly attached to her father and sister that, but for these higher ties, a warmer love might have seemed impossible. She could never see a fault in any of them. She was not a woman of strong understanding or any quickness; and with this resemblance of her father, she inherited also much of his constitution; was delicate in her own health, over- careful of that of her children, had many fears and many nerves... (Austen, 2014).

On the other hand, John was a very careful parent and looked after his five children, but his behavior towards his wife sometimes passed all the limits. Isabella "represents an ideal of a woman of her time, weak, delicate and submissive, having a child every year, prepared to do anything to please her husband" (Dobosiova, 2006). Based on the fact that during the period of the eighteenth century "socially, women were demanded to have children and to take care of their husbands", Isabella shows an exact example of this type of woman. In the relationship of John and Isabella, Isabella is seen as a weaker person, obeying her husband's rules. As Bergen states about the women of the eighteenth century "...women and men became one single person from legal and civil point of view, and in biblical perspective they became 'one flash'. The fact that most of the times Isabella is called under the name of her husband, Mrs. John Knightley, clearly shows that Isabella was under her husband's rules and represented a dependence on her husband.

John "indulges his family's desires for visits and vacations, although he would prefer to stay at home, especially if the weather is less than perfect. He can be quite forthright, which sometimes borders on rude" (Austen, 2014).

"Emma's sister, Isabella Knightey, is a doting mother, and she is also the sort of person who is incapable of denying a request; John Knightley is on the other hand a very positive man, equally devoted to his family life, but intolerant of interference and interruptions in it" (Gillie, 2014). The marriage of John and Isabella represents a typical marriage of the eighteenth century when women obeyed men's rules. Being a quiet person, Isabella was used to her husband's rules and had accepted that kind of life. They represented a family where John took most of the decisions. Even though things were organized in this way, again Austen does not describe Isabella to be unhappy. 
Isabella was happy to live this kind of life, taking care of her children and her husband. She seemed to be satisfied with what she had. With the marriage of John and Isabella, Austen depicts another type of marriage showing that even in patriarchal family things can function correctly, depending on what people like and on how people prefer to live. John and Isabella loved each other, John showed great respect towards Isabella's family, but he wanted to follow a typical tradition of the eighteenth century, where men were the leaders of the family. As long as Isabella was happy with this marriage, agreeing with her husband and respecting him was the only thing she thought to make her marriage function properly. Isabella would not sacrifice her marriage and her family in order to show superiority. She was satisfied with what she had and lived her life according to what she was used to during all these years.

Based on all these issues, Austen shows that during the period of the eighteenth century marriage was paradox for women of that time. Marriage was the most important thing which could guarantee a prosperous future; yet it was socially mandated, had to be undertaken, was often based upon the financial resources of the man, and ultimately resulted in the woman being mistress of her house, and little else.

\section{Conlusion}

To conclude, in Emma, Jane Austen depicts Jane Fairfax to show clearly that educated, clever girls were not valued and respected in a level they deserved. Even though Jane was educated, again she did not have many prospects in life. This entire situation gives her not many choices but to marry someone rich. As a result, she gets engaged to Frank, a handsome and rich man. To inherit the wealth of his aunt, Frank keeps his engagement with Jane a secret because he knew that his aunt would not accept his marriage to a poor girl. Jane and Frank get married after many obstacles and misunderstandings; even though, they belonged to two different social ranks. Austen tries to show that these kinds of marriages should exist for the fact that money should not be considered as the only means for marriage. Austen takes Emma as the main character of the novel to show a rich, independent woman, whose main aim in life was matchmaking. After many mistakes and after many advices she receives by Mr. Knightley, she understands that she needs to change her attitude towards herself and other people. She finally understands that she was in love with Mr. Knightley and understands that her opinion of not marrying was not what she really wanted. Mr. Knightley's feelings for Emma had begun from the beginning of the novel because he had always followed her and advised her not to take wrong steps. Their marriage shows a mutual affection and love, and Austen describes this marriage as appropriate and adequate for a couple to be happy. 
On the other hand, Austen depicts the marriage of Harriet and Martin to show a relationship based on the same social rank and more realistic for the period of the eighteenth century. Austen presents Harriet as a naïve girl, who was persuaded by Emma's words to refuse Martin's proposal and strived to be like Emma in order to achieve a higher social rank. All the difficulties she went through, including her refusal to Martin's proposal and other issues made her understand that she could not be a person she was not. This made her open her eyes and be more realistic. She understood that she loved Martin and accepted his second proposal. Austen takes the marriage of Harriet and Martin to show a realistic marriage based on the same economical and social rank, but more importantly a marriage based on love and understanding. The marriage of Elton and Augusta represents a marriage based completely on interest. Elton's wishes to marry someone rich were fulfilled by marrying Augusta, who inherited her father's wealth. On the other hand, Augusta's wishes were fulfilled to marry the vicar of the place. Through the novel their relationship is described as very cold, not based on feelings but on money and reputation.The marriage of Elton and Augusta seems to be very formal, and their relationship does not show any sign for being happily ever after. Austen shows that this marriage is based on money, and marriages based on different social ranks will never make a couple come to an equal understanding because the ideas of these two people are completely different and would never come to an equal agreement.

Amongst the married couples, Austen depicts couples whose relationship is based on love, and couples whose relationship is seen as very formal and not based on mutual affection. Austen describes the marriage of Mrs. Weston and Mr. Weston as a happy marriage, where the couple shared mutual affection, love and respect. Moreover, since Mr. Weston had a son from his previous marriage, Mrs. Weston showed a great respect towards him, making her husband even happier. On the other hand, we see the marriage of Isabella and John as a very typical relationship of the eighteenth century, where couples married and showed respects towards each other but not love and sharing of ideas. Even though, John cared about his children, again Isabella was considered as a weak person, whose ideas and opinions were not taken into account. Isabella was a woman who obeyed her husband's rules, and she had accepted the fact that this was the only way to make her family happy. This is not the type of marriage that Austen is satisfied with, so based on all the marriages and the relationships that Austen takes in her novel Emma, it is obvious that marriages based on love are better and make a family happier.

\section{References:}

1. Austen, J. (2013). Emma (the Very Illustrated Edition). eBookIt.com. Comics\& Graphic Novels. 
2. Austen, J. (2014). Emma. Irvin, CA: Xist Classics Publishing.

3. Barfoot, C.C. (1982). The Thread of Connection. Aspects of Fate in the Novels of Jane Austen and Others. Amsterdam: Rodopi.

4. Beer, P. (1974). Reader, I Married Him. New York, Hagerstown, San Francisco, London: Barnes\& Noble Books. A Division of Harper \&Row Publishers. p.46

5. Butler, M. (1986). "History, Politics, and Religion" in Jane Austen Companion. Ed. Grey, J.D. New York: Macmillan. p.101

6. Campbell, E.E. (2012). Finding Austen: The Covert Gender Politics in Emma's Marriage Plots. Dickinson College. Retrieved from http://scholar.dickinson.edu/cgi/viewcontent.cgi?article=1032\&conte $\mathrm{xt}=$ student_honors

7. Dobosiova, M. (2006). Marriage and Human Relationships in the Eighteenth Century England, Masaryk University, p.12-15

8. Gilbert, M.S; Gubar, S. (2000). The Madwoman in the Attic: The Woman Writer and the Ninteenth-Century Literary Imaginaton. Yale University Press. p.157

9. Gillie, C. (2014). A Preface to Jane Austen. Routledge. p.136

10. Hall, A, L. (2017). Women and 'Value' in Jane Austen's Novels: Setting, Speculating and Superfluity. Springer, p.105

11. Kaye- Smith, Sh; Stern, G.B. (1943). Talking of Jane Austen. London, Toronto, Melbourne and Sydney: Casell and Company

12. Lambdin, C; Lambdin, R.T. (2000). A Companion to Jane Austen Studies. Westport, Connecticut, London: GREENWOOD PRESS. p.43-45 